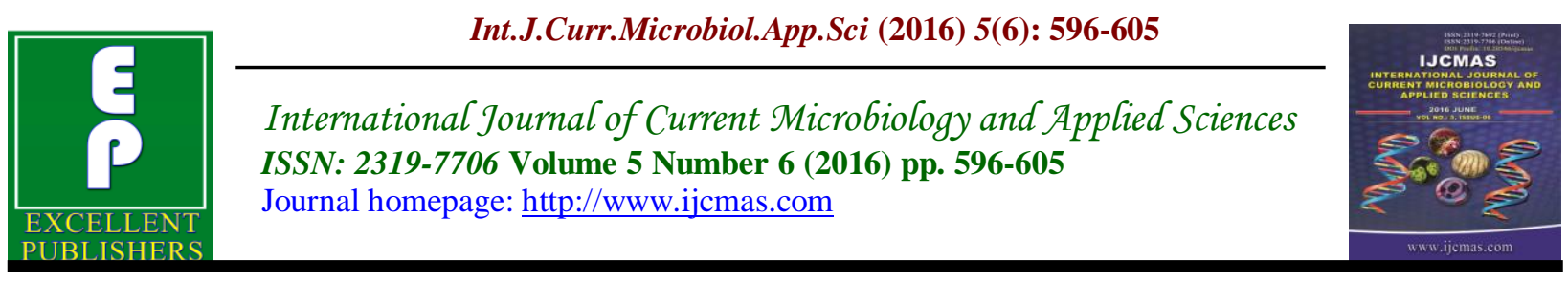

Original Research Article

http://dx.doi.org/10.20546/ijcmas.2016.506.064

\title{
Treatment of Dye Industry Effluent Using Immobilized Bacteria and Fungi Isolated from Freshwater Pond Thiruvarur District, Tamil Nadu, India
}

\author{
V. Arumugam ${ }^{1}$ and R. Sivakami ${ }^{2 *}$ \\ ${ }^{1}$ P.G. \& Research Department of Zoology, Thiru. Vi. Ka. Government Arts College, \\ Thiruvarur-610 003, India \\ ${ }^{2}$ P.G \& Research Department of Zoology, Arignar Anna Govt. Arts College, \\ Musiri - 621 211, Tamil Nadu, India \\ *Corresponding author
}

\begin{tabular}{ll}
\hline & A B S T R A C T \\
\cline { 2 - 3 } Key word s & $\begin{array}{l}\text { It is now becoming clear that fungi can also play an important role in degrading } \\
\text { organic materials and have the potential for remediating contaminated soils and } \\
\text { water. Keeping this in mind, the present study was aimed to know the efficiency of } \\
\text { immobilized bacteria and fungi of selected microbial species in textile dye industry } \\
\text { effluent, } \\
\begin{array}{l}\text { Bacteria, } \\
\text { Fungi, }\end{array}\end{array}$ \\
$\begin{array}{l}\text { Remediation. } \\
\text { recorded a decrease in their levels in all the three experimental setups when } \\
\text { compared to the control. This shows that both bacteria and fungi have the ability to } \\
\text { treat waste water. Nevertheless, the present study does not record the maximum }\end{array}$ \\
$\begin{array}{l}\text { Accepted: } \\
\text { 20 May 2016 } \\
\text { Available Online: } \\
\text { 10 June 2016 }\end{array}$ & $\begin{array}{l}\text { removal efficiencies. However, the study does indicate promising results for } \\
\text { setups, it appears that a combination of bacteria (Pseudomonas aeruginosa) and } \\
\text { fungi (Fusarium oxysporum) together appears to work better rather than using them } \\
\text { alone. Thus, it appears that the combination has a synergistic effect. }\end{array}$
\end{tabular}

\section{Introduction}

Today, synthetic dyes are being extensively used in both textile and dyeing industries because of their ease and cost effectiveness in synthesis. In addition, these dyes are also used in leather, pulp and paper, food processing, cosmetics and pharmaceutical industries. However, among the various industries, textile industries are alone considered as one of the major consumers of dyes in the market (Namdhari et al., 2012).

More than 10,000 dyes are commercially available with an estimated annual production of $7 \times 10^{5}$ metric tonnes. About $2,80,000$ tonnes of textile dyes are discharged as industrial effluents worldwide (Mass and Chaudhari, 2005). Among the various dyes, the most commonly used ones are of the reactive type with a world market share of about $60-70 \%$.

Due to the inefficiencies of the dyeing process, approximately $10-15 \%$ of the dyes used in textile industries remain unutilized and along with the reactive dyes, about $50 \%$ are released along with the effluents 
(Namdhari et al., 2012). Among the various industrial effluents, the textile and the dye industry waste play a significant role in water pollution. Discharge of these effluents into aquatic systems not only causes formation of toxic aromatic amines under anaerobic conditions but also have an adverse effect in terms of chemical oxygen demand in the receiving media. Further, many of these dyes are toxic, mutagenic and carcinogenic besides interfering with the transmission of sunlight and reducing photosynthetic activity (Chung and Stevens, 1993; Campos et al., 2001; Mc Mullan et $a l ., 2001)$ in addition to their visual effect.

Degradation of dyes is difficult due to their complex structure and synthetic nature (Swamy and Ramsay, 1999; Maas and Chaudhari, 2005). In addition, most of the dyes are resistant to light, water and oxidizing agents and so treatment by conventional processes is impossible (Shaul et al., 1991).

Currently, various physical, chemical and biological methods like adsorption, sedimentation, flocculation, neutralization, electrolysis, ion exchange etc. are employed to remove colour (Pala and Toket, 2002; Zhang et al., 2003). However, use of these methods involve huge costs besides accumulation of large quantities of sludge. Another reason is the formation of toxic byproducts. Hence, these methods have their own limitations. Thus, the efficient removal of these dyes from textile mill effluents is still a major environmental challenge. For this reason, legislation in industrialized and many developing countries have reinforced environmental laws that regulate the maximum allowed residual concentrations in purified waste water before being let off into an aquatic system. However, enforcement of these laws is not always strict and appears to be related to the economy of the country.
Thus, the type of enforcement differs significantly between wealthy and poor countries (Sankarrao, 2013).

Among the economical and environmental friendly techniques used for removal of colour or dye waste from effluents, bioremediation technology has gained considerable attention in many countries of the world (Ritmann et al., 1988; Enhca, 1994). Bioremediation using indigenous microorganisms like bacteria, algae and fungi are used in the treatment of dye effluents. Among these, bacteria are most commonly used for various bioremediation processes. Decolorisation generally occurs by the adsorption of dyestuffs on bacteria rather than oxidation in aerobic systems. Some bacteria can also degrade dyestuffs by azoreductase activity. However, the effluent at the end of the biotransformation of dyestuff can become toxic (Chung and Stevens, 1993). These problems limit the large scale application of bacterial decolorisation.

Among the fungi, literature reveals that white rot fungi are efficient in biodegradation of recalcitrant compounds like xenobiotics, lignin and dyestuffs by their extracellular ligninolytic enzyme system (Brodkorb and Legge, 1992; Heinfling et al., 1997). Their extracellular enzyme systems including lignin peroxidase - manganese independent versatile peroxidases, being non specific, can attack a wide variety of complex aromatic dyestuffs (Barclay et al., 1990; Boer et al., 2004; Kamitsuji et al., 2005). Further, as the enzymes are extracellular, the substrate diffusion limitation into the cell, usually seen in bacteria is not encountered. In addition, white rot fungi do not require preconditioning to particular pollutants because enzyme secretion depends on nutrient limitation rather than the presence 
of pollutant. Thus, it is now becoming clear that fungi can also play an important role in degrading organic materials and have the potential for remediating contaminated soils and water. Keeping all these in mind, the present study was aimed to: 1 . Isolate the selected bacteria and fungi from the fresh water of Vayalur temple pond. 2. Identify the isolated bacteria and fungi using biochemical tests and standard methods. 3 . Know the efficiency of immobilized bacteria and fungi of selected microbial species in textile dye industry effluent treatment.

\section{Materials and Methods}

\section{Source of Effluent}

For the present study, the textile dye industry effluent samples were collected from textile dye industry, Erode, Tamil $\mathrm{Nadu}$, India. Samples were collected in large sterilized bottles and brought to the laboratory. Physico-chemical characteristics were analysed on the same day. Before analyzing, dye effluent samples were filtered through cotton to remove suspended solids.

The waste water effluent collected was brought to the laboratory and sterilized using an autoclave at $121^{\circ} \mathrm{C}$ to kill micro organisms. This effluent was divided into four set ups. In experimental setup-I, Pseudomonas aeruginosa (bacteria) was added (10 $\mathrm{ml}$ of broth culture of bacteria in $100 \mathrm{ml}$ of sample) while in experimental setup-II, Fusarium oxysporum (fungi) was added (10 $\mathrm{ml}$ of broth culture of fungi in 100 $\mathrm{ml}$ of sample) and in experimental setup-III, Pseudomonas aeruginosa and Fusarium oxysporum (bacteria and fungi) in equal concentrations were taken. The fourth experimental setup-IV was not inoculated with any microorganism and was considered as control. The results were noted every five days till the 15 th day of inoculation.

\section{Isolation of Bacteria}

Ten millilitre of the pond water sample was taken in a $250 \mathrm{ml}$ conical flask containing 90 $\mathrm{ml}$ sterile distilled water. The flask was shaken on an electric shaker to get a homogenous suspension and transferred serially $(10 \mathrm{ml}$ of the pond water suspension was diluted to $90 \mathrm{ml}$ of sterile distilled water); different dilutions were made $\left(10^{-1}\right.$, $\left.10^{-2}, 10^{-3}, 10^{-4}, 10^{-5}\right)$; dilution was plated in Petri dishes containing nutrient agar medium. The inoculated plates were incubated at $25 \square \quad 2^{\circ} \mathrm{C}$ for one to two days and bacteria appearing over the medium were taken and mounted on a clean slide, stained with crystal violet, Grams iodine and safranine and observed under the microscope. The bacteria were identified based on colony characteristics, Gram staining methods and by various biochemical tests as given by Bergey's (1984) manual of determinative bacteriology.

\section{Biochemical tests}

The physiological and biochemical tests were conducted following the methods of Somasegaran and Hoben (1985) and Josey et al. (1979) respectively, as described by Cappuccino and Sherman (1999) to identify the bacteria.

\section{Isolation of Fungi}

Ten milliliter of the pond water sample was taken in a $250 \mathrm{ml}$ conical flask containing 90 $\mathrm{ml}$ sterile distilled water. The flask was shaken on an elastic shaker to get a homogenous suspension and transferring serially $10 \mathrm{ml}$ of the effluent suspension to $90 \mathrm{ml}$ of sterile distilled water to make different dilutions $\left(10^{-1}, 10^{-2}\right.$ and $\left.10^{-3}\right) .0 .1$ $\mathrm{ml}$ of dilution was plated in petridishes containing Potato Dextrose Agar medium 
(PDA). Streptomycin $\left(10 \mathrm{mg} \mathrm{l}^{-1}\right)$ was added to the media to prevent bacterial growth. The plates were incubated at $25 \pm 2^{\circ} \mathrm{C}$ for five days and fungi appearing on the medium were mounted over a clean slide and stained with lacto phenol cotton blue and observed under the microscope; photomicrographs were also made. The fungi were identified by using standard manuals such as the Manual of soil fungi (Gillman, 1957), Dematiacceous hyphomycetes (Ellis, 1976), more Dematiaceous hyphomycetes and Hyphomycetes (Subramanian, 1971).

\section{Immobilization of Bacteria in Alginate beads}

Sodium alginate was used as the immobilizing agent for bead preparation. Exponentially growing cells were harvested by centrifugation ( $5000 \mathrm{x} \mathrm{g}$ for $10 \mathrm{~min}$ ) and resuspended in $50 \mathrm{ml}$ of sterile water. To this, $50 \mathrm{ml}$ of $4 \%$ alginate solution was mixed thoroughly to get a final alginate concentration of $2 \%$. The alginate-bacterial mixture was then added drop wise into $\mathrm{CaCl}_{2}(0.1 \mathrm{M})$ solution. The beads were kept in the same solution for $30 \mathrm{mins}$ at $4^{\circ} \mathrm{C}$ for hardening.

\section{Immobilization of Fungi in Alginate Beads}

Commercial grade sodium alginate was used as the immobilizing agent for bead preparation. Exponentially growing Fusarium oxysporum, was harvested by centrifugation (5000 x g for $10 \mathrm{~min}$ ) and resuspended in $5 \mathrm{ml}$ of sterile water. To this, $50 \mathrm{ml}$ of $4 \%$ alginate solution was mixed thoroughly to get a final alginate concentration of $2 \%$. The alginated fungi mixture was then added drop wise into $\mathrm{CaCl}_{2}(0.1 \mathrm{M})$ solution. The beads were kept in the same solution for $30 \mathrm{~min}$ at $4^{\circ} \mathrm{C}$ for hardening.

Immobilization of Bacteria and Fungi

\section{(Combined) in alginate beads}

Sodium alginate was used as the immobilizing agent for bead preparation. Exponentially growing cells were harvested by centrifugation ( $5000 \mathrm{x} \mathrm{g}$ for $10 \mathrm{~min}$ ) and resuspended in $50 \mathrm{ml}$ of sterile water. To this, $50 \mathrm{ml}$ of $4 \%$ alginate solution was mixed thoroughly to get a final alginate concentration of $2 \%$ Alginate and equal concentration of bacteria and fungal mixture were then added drop wise into $\mathrm{CaCl}_{2}$ $(0.1 \mathrm{M})$ solution. The beads were kept in the same solution for $30 \mathrm{~min}$ at $4^{\circ} \mathrm{C}$ for hardening. The experiment was conducted in batch cultures in duplicates for a total period of 15 days in $250 \mathrm{ml}$ Erlenmeyer flask. Dye effluent samples (control and 179 treated) were periodically analyzed (every 5 th days) for various physicochemical parameters and recorded.

\section{Results and Discussion}

The results obtained by using the selected species of bacteria (Pseudomonas aeruginosa) and fungi (Fusarium oxysporum) in effluent treatment are presented in Table-1.

pH

The $\mathrm{pH}$ recorded in the textile dye effluent was 6.9 units. This decreased to 6.7 in all the three experimental setups by the $15^{\text {th }}$ day.

\section{Free Carbondioxide}

The initial free carbondioxide level noticed in the effluent was $35 \mathrm{mg} / \mathrm{l}$. This gradually decreased in all the three experimental setups from the 5th day onwards. Among the three setups, maximum reduction was recorded in the combination setup containing bacteria and fungi (11 mg/l), followed by fungi $(13 \mathrm{mg} / \mathrm{l})$ and bacteria 
alone (15 $\mathrm{mg} / \mathrm{l})$. The reduction of carbondioxide level in terms of percentage worked out to 68 (combination) / 62 (fungi alone) / 57 (bacteria alone) respectively. Alkalinity

The alkalinity level in the effluent was 113 $\mathrm{mg} / \mathrm{l}$ which also declined gradually in all the three experimental setups from the 5th day till the last day of the experiment. Among the three setups, the combination setup of bacteria and fungi recorded the maximum reduction $(79 \%)$, followed by bacteria $(77 \%)$ and fungi (76\%).

\section{Dissolved Oxygen}

From an initial value of $1.40 \mathrm{mg} / \mathrm{l}$ in the textile mill effluent, the oxygen level was found to gradually increase in all the three setups till the 15th day. Among the three set ups, the maximal increase of dissolved oxygen was in the combination setup $(2.5 \%)$ thus showing an increase of $78 \%$ followed by fungi $(2.4 \mathrm{mg} / \mathrm{l})$ with an increase $71 \%$ and bacteria $(2.3 \mathrm{mg} / \mathrm{l})$ recording an increase of $64 \%$ respectively.

\section{Nitrate}

The nitrate level showed a decreasing trend in all the experimental setups when compared with the effluent. Thus, from an initial level of $92 \mathrm{mg} / \mathrm{l}$ in the effluent, the level decreased to $52 \mathrm{mg} / \mathrm{l}$ (combination), 54 $\mathrm{mg} / \mathrm{l}$ (fungi) and $44 \mathrm{mg} / \mathrm{l}$ (bacteria). Hence combination setup recorded the maximum decrease $(52 \%)$ when compared to fungi $(41 \%)$ and bacteria $(48 \%)$.

\section{Nitrite}

The nitrite level also showed a similar trend as nitrate. From an initial level of $51 \mathrm{mg} / \mathrm{l}$ (effluent), the level declined to $28 \mathrm{mg} / \mathrm{l}$ showing a decrease of $45 \%$ in the combination setup. In the bacterial setup, the level was $29 \mathrm{mg} / \mathrm{l}$ thus showing a decrease of $41 \%$ while in the fungal setup the level was $31 \mathrm{mg} / \mathrm{l}$ thus showing a decrease of $39 \%$.

\section{Ammonia}

As far as ammonium levels were concerned, maximum reduction was observed in the combination setup which showed a reduction of $60 \%$ followed by both bacteria and fungi which showed an equal reduction of $55 \%$ respectively.

\section{Organic, Inorganic and Total phosphate}

The organic, inorganic and total phosphate content also decreased on the $15^{\text {th }}$ day. While the organic phosphate level decreased from an initial level of $67 \mathrm{mg} / 1$ to $31 \mathrm{mg} / \mathrm{l}$ (combination) / $33 \mathrm{mg} / \mathrm{l}$ (fungi) / 41 (mg/l) (bacteria), the inorganic phosphate level decreased from $87 \mathrm{mg} / \mathrm{l}$ to $41 \mathrm{mg} / \mathrm{l}$ (combination) / $44 \mathrm{mg} / \mathrm{l}$ (fungi) / $46 \mathrm{mg} / \mathrm{l}$ (bacteria) and the total phosphate content decreased to $80 \mathrm{mg} / \mathrm{l}$ (combination setup) / $85 \mathrm{mg} / \mathrm{l}$ (bacterial setup) / $83 \mathrm{mg} / \mathrm{l}$ (fungal setup) from an initial level of $152 \mathrm{mg} / \mathrm{l}$ on the 15 th days.

\section{Calcium}

The calcium content in all the three experimental set ups also decreased on the 15th day. Among the three experimental setups, the setup containing the combination of bacteria and fungi recorded the maximum reduction. Thus, from an initial level of 89 $\mathrm{mg} / \mathrm{l}$, the combination setup recorded a level of $51 \mathrm{mg} / \mathrm{l}$ thus showing a reduction of $42.6 \%$. This was followed by the fungal setup where the calcium level decreased to $55 \mathrm{mg} / \mathrm{l}$ recording a reduction of $38.2 \%$; the bacterial setup also showed a decline in calcium content recording $56 \mathrm{mg} / \mathrm{l}$, thus, 
showing a decrease of $37.07 \%$.

\section{Magnesium}

The magnesium level showed a decreasing trend in all the experimental setups on the $15^{\text {th }}$ day. The maximum reduction was shown in the medium which contained bacteria, followed by the combination of bacteria and fungi and finally by fungi alone. In terms of percentage reduction, it worked to $53.1 \%$ (bacteria), / $31.2 \%$ (combination) and $29.6 \%$ fungi respectively.

\section{Chloride}

The chloride concentration also showed a declining trend in all the experimental set ups. The maximum reduction was recorded in the combination set up which showed a decrease of $22.2 \%$ followed by fungi $(16.6 \%)$ and bacteria $(9.2 \%)$.

\section{BOD}

The BOD level also showed considerable reduction in all the three experimental setups. The maximum reduction was recorded in the medium containing the combination of bacteria and fungi, followed by fungi and bacteria. Thus, from an initial level of $350 \mathrm{mg} / \mathrm{l}$, BOD level decreased to $108 \mathrm{mg} / \mathrm{l}$ thereby showing a reduction of $65.1 \%$ (bacteria), followed by fungi (120 $\mathrm{mg} / \mathrm{l})$ with a reduction of $65.7 \%$ and bacteria and fungi $(170 \mathrm{mg} / \mathrm{l})$ with a reduction of $51.4 \%$.

\section{COD}

The COD level also decreased in all the three setups with the maximum being recorded in the bacterial setup followed by the combination and fungal setup. The reduction in terms of percentage worked out to $50.6 \%$ (bacteria), $49.05 \%$ (combination) and $47.4 \%$ (fungi).
The primary purpose of waste water treatment is to remove the suspended and soluble organic constituents which are measured as chemical oxygen demand (COD) or biological oxygen demand (BOD). As the bacteria were difficult to be removed from the water sample, this study was done using immobilized bacteria using sodium alginate. In addition, Ramesh and Singh (1993) have also reported that immobilized bacteria had a higher efficiency to remove suspended particles than free cells.

In the present study, $\mathrm{pH}$, free $\mathrm{CO}_{2}$ and alkalinity were found to decrease from the 5 th day onwards. The $\mathrm{pH}$ of effluent is mainly governed by the use of chemicals like bicarbonates, hydrogen peroxide and sodium hydroxide during the bleaching process in textile industry (Wood and Kellog, 1988). Among the three experimental setups, the decrease in $\mathrm{pH}$ appeared to be uniform for all the three setups. However, with regard to free $\mathrm{CO}_{2}$ and alkalinity levels, the combination set up of bacteria and fungi appeared to be the best as they showed a higher degree of reduction in free $\mathrm{CO}_{2}$ and alkalinity levels when compared to using bacteria or fungi alone.

As far as nitrogen levels were concerned, ammonia levels decreased between 55 to $60 \%$, while nitrites between 41 and $53 \%$ and nitrates between 39 and $45 \%$.

Literature reveals that Madhu and Pillai (1994) and Shimna (2012) also recorded about $50 \%$ reduction in nitrogen levels on 15 th day using bacteria and fungi in tannery effluents. Nevertheless, among the three experimental setups, the bacteria alone experimental setup worked best for nitrite reduction while the combination setup of bacteria and fungi worked best for nitrate and ammonia reduction. 
Table.1 Textile dye degradation by using microbes isolated from freshwater pond, Tamil Nadu

\begin{tabular}{|c|c|c|c|c|c|c|c|c|c|c|c|c|c|c|}
\hline \multirow[b]{2}{*}{ S. No } & \multirow[b]{2}{*}{ Parameters } & \multicolumn{5}{|c|}{$5^{\text {th }}$ Day } & \multicolumn{4}{|c|}{$10^{\text {th }}$ Day } & \multicolumn{4}{|c|}{$15^{\text {th }}$ Day } \\
\hline & & Initial & Control & Bacteria & Fungi & $\begin{array}{c}\text { Bacteria } \\
+ \\
\text { Fungi }\end{array}$ & Control & Bacteria & Fungi & $\begin{array}{c}\text { Bacteria } \\
+ \\
\text { Fungi }\end{array}$ & Control & Bacteria & Fungi & $\begin{array}{c}\text { Bacteria } \\
+ \\
\text { Fungi }\end{array}$ \\
\hline 1. & $\mathrm{PH}$ & 6.90 & 6.90 & 6.80 & 6.80 & 6.70 & 6.80 & 6.70 & 6.70 & 6.70 & 6.80 & 6.70 & 6.70 & 6.70 \\
\hline 2. & FREE $\mathrm{CO}_{2}$ & 35.00 & 33.00 & 31.00 & 27.00 & 25.00 & 33.00 & 25.00 & 23.00 & 21.00 & 31.00 & 15.00 & 13.00 & 11.00 \\
\hline 3. & Alkalinity & 113.00 & 111.00 & 83.00 & 101.00 & 99.00 & 111.00 & 67.00 & 53.00 & 51.00 & 109.00 & 15.00 & 26.00 & 23.00 \\
\hline 4. & DO & 1.40 & 1.80 & 1.90 & 2.00 & 2.10 & 2.80 & 2.00 & 2.20 & 2.30 & 2.00 & 2.30 & 2.40 & 2.50 \\
\hline 5. & Nitrate - N & 92.00 & 92.00 & 84.00 & 72.00 & 70.00 & 92.00 & 70.00 & 61.00 & 59.00 & 90.00 & 44.00 & 54.00 & 52.00 \\
\hline 6. & Nitrite - N & 51.00 & 51.00 & 49.00 & 43.00 & 41.00 & 49.00 & 39.00 & 35.00 & 33.00 & 47.00 & 29.00 & 31.00 & 28.00 \\
\hline 7. & Ammonia - N & 45.00 & 45.00 & 36.00 & 34.00 & 32.00 & 44.00 & 30.00 & 24.00 & 24.00 & 43.00 & 20.00 & 20.00 & 18.00 \\
\hline 8. & Total PO4 & 152.00 & 151.00 & 141.00 & 135.00 & 133.00 & 149.00 & 131.00 & 173.00 & 169.00 & 147.00 & 85.00 & 83.00 & 80.00 \\
\hline 9. & Inorganic PO4 & 87.00 & 86.00 & 82.00 & 27.00 & 26.00 & 84.00 & 76.00 & 66.00 & 64.00 & 82.00 & 46.00 & 44.00 & 41.00 \\
\hline 10. & Organic PO4 & 67.00 & 67.00 & 61.00 & 60.00 & 59.00 & 65.00 & 57.00 & 47.00 & 45.00 & 63.00 & 41.00 & 33.00 & 31.00 \\
\hline 11. & Calcium & 89.00 & 88.00 & 82.00 & 74.00 & 72.00 & 86.00 & 76.00 & 64.00 & 61.00 & 84.00 & 56.00 & 55.00 & 51.00 \\
\hline 12. & Magnesium & 64.00 & 63.00 & 58.00 & 58.00 & 56.00 & 62.00 & 50.00 & 53.00 & 51.00 & 62.00 & 30.00 & 45.00 & 44.00 \\
\hline 13. & Chloride & 54.00 & 49.00 & 53.00 & 49.00 & 48.00 & 45.00 & 51.00 & 47.00 & 45.00 & 53.00 & 49.00 & 45.00 & 42.00 \\
\hline 14. & BOD & 350.00 & 330.00 & 260.00 & 270.00 & 260.00 & 320.00 & 230.00 & 190.00 & 186.00 & 320.00 & 170.00 & 120.00 & 108.00 \\
\hline 15. & COD & 632.00 & 622.00 & 532.00 & 512.00 & 502.00 & 612.00 & 432.00 & 392.00 & 382.00 & 592.00 & 312.00 & 332.00 & 322.00 \\
\hline
\end{tabular}


While the inorganic, organic and total phosphate level started decreasing in all the three experimental set ups from the fifth day onwards, the maximum reduction was recorded in the combination setup, followed by the fungus and bacteria alone setup. A similar decrease in phosphate levels from the fifth day was also recorded by earlier workers (Sekaran and Mariappan, 1994; Shimna, 2012) while working on various effluents using bacteria and fungi.

A comparison of the calcium, magnesium and chloride levels also reveals a similar pattern showing a decreasing trend from the fifth to the fifteenth day. Among the three, the maximum reduction was found in the calcium level (ranging from 51 - 56\%) followed by chloride (ranging from 39.2 42.6\%) and magnesium (ranging from 29.6 $53.1 \%$ ). Further, among the various set ups, the combination setup appeared to show maximum reduction even though, exceptionally, for magnesium, the maximum reduction took place in the bacterial setup.

A perusal of the BOD and COD levels in the three experimental setups reveals that the maximum reduction in terms of BOD was recorded in the combination setup followed by the media which contained fungus and bacteria alone. While the maximum reduction in terms of COD was recorded in the bacterial setup, it was closely followed by the combination setup and fungus alone setup. Thus overall, the present study indicates that all the parameters recorded a decrease in their levels in all the three experimental setups when compared to the control. This shows that both bacteria and fungi have the ability to treat waste water. Nevertheless, the present study does not record the maximum removal efficiencies. However, the study does indicate promising results for removal for many of the parameters estimated. Brooks (1988) and
Shimna (2012) also found excellent reduction in all the parameters analyzed by them using bacteria and fungi. A similar result was also observed by Namdhari et al. (2012) when they used fungi to treat textile effluent.

Among the three experimental setups, from the present experiment, it appears that a combination of bacteria (Pseudomonas aeruginosa) and fungi (Fusarium oxysporum) together appears to work better rather than using them alone. Thus, it appears that the combination has a synergistic effect.

\section{References}

Barclay, C.D., Moore, D.M., Lander, S.R., Legge, R.L. 1990. Heat denaturation kinetics of lignin peroxidases from Phanerochaete chrysosporium. Enzyme Microb. Technol., 12: 778782.

Bergey, D.H. 1984. Bergey's manual of systematic Bacteriol., Williams and Baltimore: USA. p. 516.

Boer, C.G., Obici, L., Souza, C.G., Peralta, R.M. 2004. Decolourization of synthetic dyes by solid state cultures of Lentinula (Lentinus) edodes producing manganese peroxidase as the main lignolytic enzyme. Bioresour. Technol., 94: 107-112.

Brodkorb, T.S., Legge, R.L. 1992. Enhanced biodegradation of phenanthrene in oil tar-contaminated soils supplemented with Phanerochaete chrysosporium. Appl. Environ. Microbiol., 58: 31173121.

Brooks, J.L. 1988. The role of fungi in the sphagnum peat wastewater treatment system. Ph.D. Thesis, University of Maine, Orono, Maine.

Campos, R., Kandelbauker, A., Robra, K.L.H., Arthur, C.P., Gubitz, G.M. 
2001. Indigo degradation with purified lactases from Trametes hirsute and Sclerotim rolfsii. J. Biotechnol., 8: 131-139.

Cappuccino, J.G., Sherman, N. 1999. Microbiology; A Laboratory manual ${ }^{\text {rd }}$ edn.) J. Rockland Community College, Suffern: New York. p.45.

Chung, K.T., Stevens, S. Jr. 1993. Decolourization of azo dyes by environmental microorganisms and helminthes. Environ. Toxicol. Chem., 12: $121-131$.

Ellis, M.B. 1976. Dematiaceous Hypomycetes. Commonwealth Mycological Institute Pub., Kew Surrey, England. pp. 17.

Enhca, G. 1994. The role of microorganism in environmental decontamination. Contaminants in the environment, a multidisciplinary assessment of risk to man and other organisms. J. Exp. Mar. Biol. Ecol., 25: 235-246.

Gillman, J.C. 1957. A manual of soil fungi. Oxford and I.B.H. Publishing company (Indian reprint), Calcutta, Bombay, New Delhi., p. 250.

Heinfling, A., Bergbauer, M., Szewzyk, U. 1997. Biodegradation of azo and phthalocyanin dyes by Trametes versicolor and Bjerkandera adusta. Appl. Microbiol. Biotechnol., 48: 261-266.

Josey, D.P., Beynon, J.L., Johnston, A.W.B., Beringer, J.E. 1979. Strain identification in Rhizobium using intrinsic antibiotic resistance. $J$. Gen. Microbiol., 10: 1365-2672.

Kamitsuji, H.Y., Watanable, T., Kuwahara, M. 2005. Mn is dispensable for the production of active $\mathrm{MnP}_{2}$ by Pleurotusx ostreatus. Biochem. Biophys. Res. Comm., 327: 871-876.

Maas, R., Chaudhari, S. 2005. Adsorption and biological decolorization of azo dye reactive red in semicontinnuous anaerobic reactors. Process Biochem., 40: 699-705.

Madhu, G., Pillai, K.A. 1994. Biological treatment of effluent from a nitrogenous fertiliser complex. Indian science Annual, 22: 64-70.

McMullan, G., Robinson, T., Marchant, R., Nigam, P. 2001. Remediation of dyes in textile effluent: a critical review on current treatment technologies with proposed alternatives, Biosource Technol., 77: 247-255.

Namdhari, B.S., Rohilla, S.K., Salar, R.K., Gahlawat, S.K., Bansal, P., Saran, A.K. 2012. Decolorization of Reactive Blue MR using Aspergillus species isolated from textile waste water. Phykos, 1: 24-29.

Pala, A., Toket, E. 2002. Color removal from cotton textile industry wastewater by an activated sludge system with various additives. Water Res., 36: 2920-2925.

Ramesh, J.V.S., Singh, S.P. 1993. Yearly variation in certain physicochemical parameters of pond at eastern Doon Valley, Uttar Pradesh. J. Zoo., 12: 75-77.

Ritmann, B.E., Jacson D.E., Strock, S.L. 1988. American public health potential for treatment of hazardous organic chemical with biological process. Hydrobiol., 15:64.

Sankar Rao, M. 2013. A study on seasonal variations of microorganisms in temple ponds and its role in antimicrobial activity. Ph.D. Thesis, Bharathidasan University, Tiruchirappalli.

Sekaran, G., Mariappan, M. 1994. Treatment of salt laden wastewater from tanning industry. Indian J. Environ. Prot., 14: 801-806.

Shaul, G.M., Holdworth, T.J., Dempsey, C.R., Dostal, K.A. 1991. Fate of 
water soluble azo dyes in the activated sludge process. Chemosphere. 22:107-119.

Shimna, P.P. 2012. Microbial diversity and abundance of ponds of subtropical India. Ph.D. Thesis, Bharathidasan University, Tiruchirappali, India.

Somasegaran, P., Hoben, H. 1985. Methods in Legume Rhizobium Technology, University of Hawaii, Niftal. Project and Micren, Department of Agronomy and Soil., pp. 1-300.

Subramanian, C.V. 1971. Hyphomycetes An account of Indian species except Cercosporae. ICAR, New Delhi. evaluation of white-rot fungi in the decolourization of textile dyes. Enzyme Microb. Technol., 24: 130137.

Wood, W.A., Kellogg, S.T. 1988. Biomass, cellulose and hemicelluloses methods. Enzymol., 160: 623-634.

Zhang, S.J., Yang, Q.X., Zhang, Y., Xin, B.P., Pan, F. 2003. Biosorption of reactive dyes by mycelium pellets of a new isolate of Penicllium oxalicum. Biotechnol. Lett., 25: 1479-1488.

Swamy, J., Ramsay, J.A. 1999. The

\section{How to cite this article:}

Arumugam, V., and Sivakami, R. 2016. Treatment of Dye Industry Effluent Using Immobilized Bacteria and Fungi Isolated from Freshwater Pond Thiruvarur District, Tamil Nadu, India. Int.J.Curr.Microbiol.App.Sci. 5(6): 596-605. doi: http://dx.doi.org/10.20546/ijcmas.2016.506.064 